Published every April, August and December

JURNAL RISET AKUNTANSI \& KEUANGAN

ISSN:2541-061X (Online). ISSN:2338-1507(Print). http://ejournal.upi.edu/index.php/JRAK

\title{
Analisis Kelayakan Finansial Industrialisasi Rumput Laut ATC Chips di Tujuh Propinsi Indonesia Timur
}

\author{
Bambang Susanto ${ }^{1}$, Sukadwilinda ${ }^{2}$ \\ Program Studi Akuntansi, Fakultas Ekonomi, Universitas Sangga Buana - YPKP, Bandung, Indonesia
}

\begin{abstract}
Indonesia has one of the largest wet seaweed producer in the World. It will impact the economic value if the seaweed processing industry small and medium-scale can be established disentra seaweed production centers such as in Eastern Indonesia. The establishment of the seaweed industry small and medium-scale can be realized through several approaches, both economic and financial approach. The research method using descriptive analytic with field surveys as reinforcement data analysis. The object of this study is the financial analysis of the seaweed industry in Indonesia, especially in eastern regions such as South Sulawesi, Central Sulawesi, North Sulawesi, West Nusa Tenggara, East Nusa Tenggara, Maluku and North Maluku. The results of the financial analysis of the overall approach to demonstrate the positive zone seen from the feasibility, both $N P V, I R R$, and Payback Ratio ratio $B C$

Keywords: industrialization; ATC chips; financial analysis.

Abstrak. Indonesia merupakan salah satu negara penghasil rumput laut basah terbesar di Dunia. Ini akan membawa dampak nilai ekonomis yang menjanjikan jika industri pengolahan rumput laut skala kecil dan menengah dapat didirikan disentra sentra penghasil rumput laut seperti di Indonesia Timur. Pendirian industri rumput laut berskala kecil menengah dapat direalisasi melalui beberapa pendekatan, baik pendekatan ekonomi maupun finansial. Metode penelitian yang dilakukan dengan menggunakan metode diskritif analitik dengan survei lapangan sebagai penguat analsisi data.Objek penelitian ini adalah analisis Finansial industri rumput laut di Indonesia khususnya wilayah timur seperti Sulawesi Selatan, Sulawesi Tengah, sulawesi utara, Nusa Tenggara barat, Nusa Tenggara Timur, Maluku serta Maluku Utara. Hasil analisis finansial dari keseluruhan pendekatan menunjukkan zona positif dilihat dari kelayakannya, baik NPV, IRR, BC Ratio maupun Payback Rationya
\end{abstract}

Kata Kunci: industrialisasi; ATC chips; analisis finansial.

Corresponding author. Email: bambangsusanto18@gmail.com ${ }^{1}$, sukadwilinda@gmail.com²

How to cite this article. Susanto, B. (2017). Analisis Kelayakan Finansial Industrialisasi Rumput Laut ATC Chips di Tujuh Propinsi Indonesia Timur. Jurnal Riset Akuntansi Dan Keuangan Program Studi Akuntansi Fakultas Pendidikan Ekonomi Dan Bisnis Universitas Pendidikan Indonesia, 5(1), $1293-1306$. https://doi.org/10.17509/jrak.v5i1.6732

History of article. Received: February 2017, Revision: March 2017, Published: April 2017

Online ISSN: 2541-061X. Print ISSN: 2338-1507. DOI :10.17509/jrak.v5i1.6734

Copyright@2017. Published by Jurnal Riset Akuntansi dan Keuangan. Program Studi Akuntansi. FPEB. UPI 


\section{PENDAHULUAN}

Rumput laut (seaweed) merupakan salah satu komoditi yang potensial dan dapat menjadi andalan bagi upaya pengembangan industri kecil dan menengah yang sering disebut sebagai IKM. Ini terjadi karena rumput laut sangat banyak digunakan oleh manusia, baik melalui pengolahan sederhana yang langsung dikonsumsi maupun melalui pengolahan yang lebih kompleks untuk dijadikan barang setengah jadi dan diolah lebih lanjut oleh industri hilir menjadi barang jadi yang dapat digunakan (dikonsumsi) langsung, seperti produk farmasi, kosmetik dan pangan serta produk lainnya yang lebih dari 500 varian turunan atau End product.

Indonesia memiliki potensi pengembangan rumput laut yang cukup besar, $85 \%$ rumput laut basah Dunia berasal dari indonesia, khususnya Indonesia Timur, sedangkan sisanya dipasok dari Philipina (15\%). Rumput laut merupakan salah satu hasil laut yang telah diperdagangkan secara luas dalam perdagangan internasional.

Secara umum atau nasional hasil rumput laut indonesia di Ekspor ke China, ini dilakukan mengingat belum adanya industrialisasi rumput laut disentra sentra penghasil rumput laut. Belum adanya industrialisasi rumput laut berskala IKM disebabkan terbatasnya sumberdaya manusia yang memiliki skill di bidang budidaya rumput laut, mesin/peralatan pengolahan rumput laut yang masih tradisional dan faktor pemasaran yang belum menjanjikan.

Dalam rangka mendukung terciptanya nilai tambah atau End Product bisa dinikmati didalam negeri dipandang perlu industrialisasi atau pendirian pabrik pengolahan rumput laut bisa direalisasikan di Indonesia, khususnya Indonesia Timur : Sulawesi, NTT, NTB dan Maluku.

Sebelum pendirian industri rumput laut berskala IKM dapat dilakukan, tentunya harus dibuat studi kelayakan khususnya kelayakan Finansial agar diperoleh suatu gambaran dan atau masukan bagi pemerintah dan instansi terkait dalam pengambilan keputusan dan kebijakan pengembangan industri kecil dan menengah pengolahan rumput laut ke depan agar dapat memperkuat dan mempercepat pertumbuhan ekonomi di wilayah Indonesia bagian timur.

\section{KAJIAN LITERATUR}

Rumput laut dibagi dalam empat kelas yaitu : Chlorophyceae (ganggang hijau), Rhodophyceae (ganggang merah), Cyanophyceae (ganggang biru), Phaeophyceae (ganggang coklat). Dari keempat kelas tersebut hanya dua kelas yang banyak digunakan sebagai bahan mentah industri, yaitu :Rhodophyceae (ganggang biasa) yang antara lain terdiri dari : a) Gracilaria, Gelidium sebagai penghasil agaragar; b) Chondrus, Eucheuma, Gigartina sebagai penghasil karaginan.; c) Fulcellaria sebagai penghasil fulceran; d) Phaeophyceae (ganggang coklat) yang antara lain terdiri dari : Ascephyllum, Laminaria, Macrocystis sebagai penghasil alginat.

Secara nasional, potensi rumput laut mencapai 1,2 juta ha dengan areal yang cocok untuk budidaya rumput laut seluas 1.110.900 ha. Potensi tersebut tersebar di 15 provinsi dengan potensi terbesar di Papua seluas 501.000 ha, Maluku seluas 206.000 ha, Sulawesi Tengah seluas 106.300 ha, Aceh seluas 104.100 ha, Sulawesi Tenggara seluas 83.000 ha, dan provinsi-provinsi yang lain. Potensi produksi rumput laut kering rata-rata mencapai 16 ton per ha per tahun. Apabila seluruh luas areal potensial tersebut dimanfaatkan secara optimal, total produksi rumput laut kering mencapai 17.774.400 ton per tahun. Harga di pasaran dunia saat ini sekitar Rp 4,5 juta per ton. Dengan demikian, nilai pendapatan yang diperoleh dari rumput laut kering sebesar Rp 79,984 triliun. Total produksi rumput laut basah nasional rata-rata 223.000 ton atau setara dengan 30.000 ton kering. Setiap 8 (delapan) ton rumput laut basah bisa menghasilkan 1 (satu) ton rumput laut kering. Pohon industri rumput laut dapat dilihat pada Gambar berikut. 


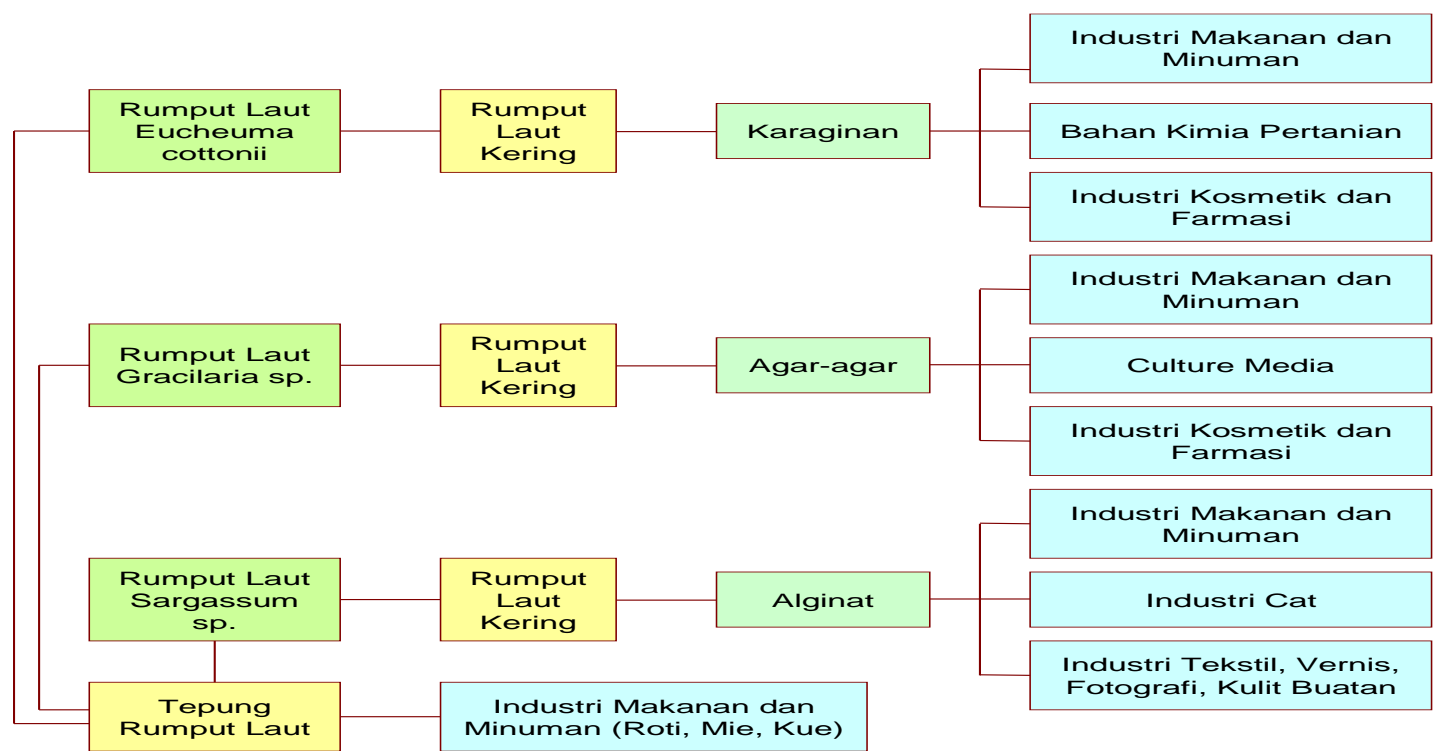

\section{Gambar 1. Pohon Industri Komoditas Rumput Laut}

Pengembangan komoditi rumput laut sebagai fokus dari salah satu produk atau komoditas unggulan sektor kelautan dan perikanan merupakan langkah strategis yang dipilih dengan pertimbangan bahwa: (1) pada tingkat pengembangan budidaya memiliki daya serap tenaga kerja yang tinggi, teknologi budi daya yang sederhana, masa tanam yang relatif pendek sekitar 45 hari (quick yield) dan biaya per unit produksi relatif sangat murah; (2) pada tingkat pengolahan hasil rumput laut melalui pengembangan industri pengolahan rumput laut memerlukan dukungan sektor lain. Indonesia selaku negara produsen rumput laut dunia pada tahun 1998-2002 masih berada pada peringkat ke-lima, setelah Philipina, China, Jepang dan Korea. Perkembangan hingga tahun 2006, Indonesia dapat mencapai peringkat keempat produsen utama dunia setelah Chili, Maroko dan Philipina. Bila dilihat perkembangan produksi rumput laut sejak tahun 2007 dengan target rata-rata per tahun 60 persen, maka peluang menjadi produsen utama rumput laut dunia pada tahun 2016 akan dapat tercapai.

Permintaan perdagangan internasional rumput laut yang dapat dikonsumsi terus meningkat sejak 50 tahun terakhir. Kebutuhan tersebut tidak dapat dipenuhi secara keseluruhan dari cadangan alami dan sekarang sekitar 90 persen berhasil dipasok dari hasil budidaya. Industri ekstrasi rumput laut terus berkembang setelah Perang Dunia II, sehingga mulai terjadi kekurangan bahan baku dari alam dan mendorong usaha budidaya berkembang pesat. Ekstraksi rumput laut menghasilkan 3 (tiga) jenis hydrocolloids, senyawa pengental dan pembentuk jelly yang meliputi alginat, agaragar dan karaginan. Dengan perhitungan kasar, 1 (satu) juta ton rumput laut basah yang diekstrak dapat menghasilkan hydrocolloids sebesar 55.000 ton dengan nilai USD 585 juta. Raksasa industri hydrocolloids berada di Denmark dan Amerika Serikat.

Pertama ALGINAT mulai diproduksi secara komersial sejak tahun 1930. Alginat umumnya diekstrak dari rumput laut coklat yang sekarang banyak dibudidayakan karena harganya mulai mahal untuk memenuhi kebutuhan industri. Nilai produksi tahunan alginat sekitar USD 213 juta. Penggunaan alginat sangat luas mulai dari industri briket batubara, kosmetik keramik, keju, es krim, pasta gigi, cat, ban, semir dan kertas. Tak tertutup kemungkinan penggunaan produk turunan dari rumput laut ini semakin meluas lagi di masa mendatang.

Pertama AGAR-AGAR ditemukan pada tahun 1658 di Jepang dari hasil ekstraksi algae merah dengan air panas. Saat ini produksi agar-agar sebagian besar menggunakan rumput laut hasil budidaya. 
Kebutuhan agar-agar dunia mencapai 10.000 ton per tahun dengan konsumen utama: Jepang (2.000 ton per tahun), Amerika Serikat (1.000 ton per tahun dimana 80 persen berasal dari impor), dan Jerman (210 - 400 ton per ton). Negara Asia yang banyak menggunakan agar-agar antara lain Thailand, Singapura dan Malaysia.

Kedua KARAGINAN telah dikenal sejak abad 19 dan semula dikembangkan dari rumput laut merah kecil Irish Moss yang biasa tumbuh di perairan dingin. Industri karaginan berkembang pesat dengan ditemukan berbagai jenis rumput laut lain yang mengandung karaginan tinggi dan dapat dibudidayakan di perairan tropis dengan biaya relatif lebih murah. Volume pasar produk karaginan mencapai 15.00020.000 ton per tahun yang tersebar di Eropa (35 persen), Asia Pasifik (25 persen), Amerika Utara (25 persen), dan Amerika Selatan (15 persen). Mayoritas penggunaan karaginan untuk kebutuhuan industri makanan dan minuman, serta industri kosmetik dan farmasi.

Terdapat 2 (dua) kelompok rumput laut yang telah menjadi produk budidaya bernilai ekonomi, yaitu Gracilaria sp. dan Eucheuma sp. Kedua rumpun ini telah berhasil dibudidayakan dan telah diperdagangkan secara luas karena dibutuhkan dalam jumlah besar sebagai bahan baku industri. Indonesia dengan pantai yang dimilikinya juga tengah membidik 2 (dua) rumpun rumput laut tersebut.

Kelompok agrofit (Gracilaria) memberikan hasil olahan berupa agar-agar (tepung, batang dan lembaran agar), sedangkan kelompok karaginofit memberikan hasil olahan berupa tepung karaginan. Kedua kelompok tersebut memiliki karakteristik yang berbeda secara biologis maupun bisnis, sehingga membutuhkan strategi pengembangan yang berbeda. Kelompok pertama memiliki nilai jual yang relatif rendah, karena kebutuhan dunia industri terhadap hasil ekstraksi kelompok agrofit lebih terbatas terutama untuk keperluan dalam negeri, sebagai pakan organisme herbivora, seperti abalone dan ikan baronang, media bakteri, industri makanan dan minuman, serta industri farmasi.

\section{METODOLOGI PENELITIAN}

Dalam penelitian ini metode yang digunakan adalah metode disriptif eksploratif dengan metode pengumpulan datanya dilakukan dengan survey lapangan serta Aspek Ekonomi dan Finansial menjadi pokok bahasan. Analisis kelayakan ekonomi dilakukan untuk mengetahui kelayakan pengembangan dari industri pengolahan rumput laut skala IKM.

Analisis data yang digunakan dalam kegiatan ini dilakukan secara kualitatif dan kuantitatif. Analisis kualitatif dilakukan untuk mengetahui kelayakan pengembangan Industri pengolahan rumput laut skala IKM yang ada dan yang akan dikembangkan dilihat aspek ekonomi.

Analisis kuantitatif dilakukan untuk menganalisis aspek finansial. Analisis finansial mengolah data menggunakan kriteria kelayakan investasi NPV (Net Present Value), IRR (Internal Rate of Return), Net B/C (Net Benefit per Cost), dan PBP (Pay Back Period). Selain itu, dilakukan pula analisis sensitivitas untuk melihat kepekaan masing-masing pengembangan dalam menghadapi kemungkinan perubahan.

a. Pay Back Peride (PBP)

Discounted payback periode (periode pengembalian kembali yang didiskontokan atau tingkat pengembalian investasi merupakan metode yang mengukur periode jangka waktu atau jumlah tahun yang dibutuhkan untuk menutupi pengeluaran awal (investasi).

$$
M=\sum(R k-E k)(P / V, i \%, k)-t
$$

b. Net Prenset Value (NPV)

Net Present Value (NPV) adalah selisih nilai sekarang dari penerimaan (manfaat) dengan nilai sekarang pengeluaran 
(biaya) pada tingkat bunga tertentu. Rumus yang digunakan :

$\mathbf{N P V}=\sum_{t=0}^{n} \frac{B t-C t}{(1+i) t}$

\section{c. Internal Rate of Return (IRR)}

Internal Rate of Return (IRR) adalah tingkat suku bunga (discount rate) yang membuat nilai NPV proyek sama dengan nol. Nilai IRR diperoleh dengan menggunakan rumus sebagai berikut :

$$
\mathbf{I R R}=\boldsymbol{i}+\frac{N P V}{N P V-N P V^{\prime}}\left(\boldsymbol{i}^{\prime}-\boldsymbol{i}\right)
$$

d. Metode Net Benefit Cost Ratio (Net B/C Ratio)

Net Benefit Cost Ratio (Net B/C Ratio) merupakan perbandingan antara nilai sekarang (present value) dari net benefit yang positif dengan net benefit yang negatif. Rumus yang digunakan:

$$
\begin{aligned}
\text { Net } \mathrm{B} / \mathrm{C}=\frac{\sum_{t=0}^{n} \frac{B t-C t}{(1+i)^{\prime}}}{\sum_{t=0}^{n} \frac{B t-C t}{(1+i)^{\prime}}} \\
\text { dimana } ; \frac{(B t-C t>0}{(B t-C t<0)}
\end{aligned}
$$

Memaparkan tentang desain penelitian yang digunakan (metode, jenis data, sumber data, teknik pengumpulan data, teknik analisis data, variabel dan pengukuran variabel) yang ditulis dalam bentuk paragraf mengalir (tidak dibuat numbering)

\section{HASIL DAN PEMBAHASAN}

Dalam membuat analsisis kelayakan industrialisasi ATC Chips di Tujuh Propinsi Indonesia Timur, peneliti menggunakan sebagian data primer dari hasil survei lapangan serta memasukkan asumsi asumsi dasar yang dijadikan pijakan perhitungan kelayakan finansial.

\section{Asumsi Dasar}

Asumsi-asumsi dasar yang dipakai dalam pengkajian pendirian pabrik ATC kapasitas $200 \mathrm{~kg}$ rumput laut kering/proses atau 1000 Kg rumput laut kering/hari adalah :
Untuk yang pertama Umur ekonomis proyek adalah 11 tahun, dimana 1 tahun merupakan masa persiapan lahan dan konstruksi serta 10 tahun adalah periode produksi/operasi sesuai dengan umur ekonomis mesin dan peralatan.

1. Kapasitas produksi adalah sebagai berikut :
a. Kapasitas olah : 1000 Rumput Laut Kering /hari
b. Jam operasi $\quad: 8$ jam per hari
c. Hari operasi : 25 hari/bulan atau 300 hari/tahun

d. Produksi akhir : ATC Chips dengan harga Rp. 46.000,- /Kg

e. Harga Bahan Rumput Laut Kering dipakai harga tertinggi yaitu pada saat diperoleh data lapangan yaitu Rp. $5.500,-/ \mathrm{Kg}$

2. Sumber dan struktur permodalan berasal dari modal sendiri $100 \%$.

3. Tingkat suku bunga bank per tahun diasumsikan adalah $15 \%$ untuk kredit Investasi dan $15 \%$ untuk kredit modal kerja.

4. Harga bahan baku dan produksi akhir didasarkan pada harga tahun 2014/2015

7. Pabrik mulai beroperasi pada tahun ke-1 dengan kapasitas 50\%, tahun ke2 beroperasi $75 \%$ dan tahun ke-3 sampai ke-10 pabrik beroperasi penuh (100\%) dan tahun ke - 0 digunakan untuk masa persiapan dan konstruksi.

8. Biaya penyusutan dihitung dengan metode garis lurus (straight-line method) yang disesuaikan dengan umur ekonomis masing-masing modal tetap.

9. Biaya perbaikan dan perawatan modal tetap dengan kisaran $1,5-2.5 \%$ pertahun dari nilai investasi barang.

\section{Perkiraan Modal Proyek}

Modal proyek yang dimaksud dibagi dalam dua bagian, yaitu modal investasi dan modal kerja. Modal investasi adalah semua modal yang diperlukan dari tahap pra 
operasi sampai pabrik siap beroperasi atau berproduksi. Modal kerja adalah modal yang diperlukan agar pabrik dapat berjalan dan memproduksi barang sebagaimana mestinya.

\section{(1) Modal Investasi}

Pembangunan pabrik ATC Chips membutuhkan modal investasi sebesar Rp 3.625.454.000,- dengan komposisi biaya yang disajikan pada Tabel dibawah.

Tabel 1. Modal Investasi

\begin{tabular}{|c|c|c|c|}
\hline Uraian & Jml & Satuan & Nilai (Rp) \\
\hline \multicolumn{4}{|l|}{ Modal Tetap } \\
\hline A. Penyiapan tanah 5000 M3 dan Amdal & 1 & Paket & 150.000 .000 \\
\hline B. Bangunan dan Pekerjaan sipil & & & 2.225.454.000 \\
\hline 1. Bangunan Limbah & 1 & Unit & \\
\hline 2. Pekerjaan pagar, Gerbang \& Jembatan & 1 & Unit & \\
\hline 3. Bagian Bak Pengolahan dan Rumah Pompa & 1 & Unit & \\
\hline 4. Bagian Pekerjaan Strukutur & 1 & Unit & \\
\hline 5. Bagian Kantor Administrasi & 1 & Unit & \\
\hline 6. Bagian Pos Keamanan & 1 & Unit & \\
\hline 7. Bagian Struktur Workshop & 1 & Unit & \\
\hline $\begin{array}{c}\text { C. Mesin dan Peralatan (KAPASITAS } 200 \\
\text { KG/PROSES) }\end{array}$ & & & 1.250 .000 .000 \\
\hline $\begin{array}{l}\text { 1. Mesin Pembersih Garam dan Kotoran/Sistem } \\
\text { Rotasi }\end{array}$ & 1 & Unit & \\
\hline 2. Bak Perendam Alkali Treatment & 3 & Unit & \\
\hline 3. Bak Pencucian & 1 & Unit & \\
\hline 4. Mesin pemotong/ Chopper & 1 & Unit & \\
\hline 5. Mesin Pengering / Dryer & 1 & Unit & \\
\hline 6. Pemanas / Thermal Oil & 1 & Unit & \\
\hline 7. Hoise Crane & 1 & Unit & \\
\hline 8. Genset $30 \mathrm{KVA}$ & 1 & Unit & \\
\hline 9. Timbangan Gantung kapasitas $500 \mathrm{Kg}$ & 1 & Unit & \\
\hline 10. Peralatan Laboratorium dan Kontrol Kualitas & 1 & paket & \\
\hline 11. Pembangunan Sumber air & 1 & Paket & \\
\hline 12. Stasiun Power Plant & 1 & Paket & \\
\hline Total Investasi & & & 3.625.454.000 \\
\hline
\end{tabular}

Sumber : data primer diolah

Tabel 2. Modal Kerja

\begin{tabular}{cccc}
\hline Uraian & Jml Satuan & $\begin{array}{c}\text { Harga } \\
\text { sat/bln } \\
(\mathrm{Rp})\end{array}$ & Total Nilai
\end{tabular} Jumlah 3 Bulan

A. Bahan baku \&

Penolong

$\begin{array}{cccrrr}\begin{array}{c}\text { Kebutuhan Bahan } \\ \text { Baku RL Kering }\end{array} & 750 & \text { Kg/hari } & 5.500 & 103.125 .000 & 309.375 .000 \\ \text { KOH } & 53 & \text { Kg/hari } & 15.0000 & 19.687 .500 & 59.062 .500 \\ \text { KCL } & 4 & \text { Kg/hari } & 13.000 & 1.218 .750 & 3.656 .250 \\ \quad \text { Sub Total } & & & & 124.031 .250 & 372.093 .750\end{array}$


B. Biaya Energi \& kemasan

1. Biaya Kemasan

2. Biaya BBM Solar

$225 \mathrm{Kg} / \mathrm{hari}$

500

2.812 .500

8.437 .500

3. Biaya Energi Listrik

Liter/hari

8.000

12.000 .000

36.000 .000

$75 \quad$ Kwh/hari

878

1.646 .250

4.938 .750

16.458.750

49.376 .250

C. Biaya Personal langsung

Tenaga Kerja tak

13.250 .000

39.750 .000

D. Biaya Opr

\&personal tdk

langsung

1. Biaya tenaga kerja

14.000 .000

42.000 .000

tak lngsung

2. Biaya Admin, Kom

20.000 .000

60.000 .000

\& Pemsrn

Sub Total

34.000.000

102.000 .000

TOTAL Biaya

187.740.000

563.220 .000

Sumber : data primer diolah

Tabel 3. Rincian Biaya Perbaikan dan Perawatan

\begin{tabular}{cccr}
\hline Fasilitas & Nilai Investasi & Biaya perwtn/th (\%) & $\begin{array}{c}\text { Biaya Prwtn per } \\
\text { /thn (Rp) }\end{array}$ \\
\hline $\begin{array}{c}\text { Bangunan } \\
\text { Mesin dan Peralatan } \\
\text { Total }\end{array}$ & 2.225 .454 .000 & $1.5 \%$ & 33.381 .810 \\
& 1.250 .000 .000 & $2.5 \%$ & 31.250 .000 \\
& & & $\mathbf{6 4 . 6 3 1 . 8 1 0}$ \\
\hline
\end{tabular}

Sumber : data primer diolah

Tabel 4. Besarnya Biaya Produksi Per Tahun

\begin{tabular}{|c|c|c|c|c|}
\hline Jabatan & $\begin{array}{l}\text { Jumlah } \\
\text { (orang) }\end{array}$ & $\begin{array}{r}\text { Gaji/ora } \\
\text { ng (Rp) } \\
\end{array}$ & $\begin{array}{l}\text { Gaji/Bulan } \\
\text { (Rp) }\end{array}$ & $\begin{array}{r}\text { Gaji/Tah } \\
\text { un (Rp) } \\
\end{array}$ \\
\hline \multicolumn{5}{|l|}{ 1. Pekerjaan Tidak Langsung } \\
\hline 1. Direktur & 1 & 5.000 .000 & 5.000 .000 & $\begin{array}{r}65.000 .0 \\
00\end{array}$ \\
\hline 2. Manajer Produksi & 1 & 3.000 .000 & 3.000 .000 & $\begin{array}{r}39.000 .0 \\
00\end{array}$ \\
\hline 3. Manajer Pemasaran & 1 & 4.000 .000 & 4.000 .000 & $\begin{array}{r}52.000 .0 \\
00\end{array}$ \\
\hline 4. Staf non Produksi & 2 & 1.000 .000 & 2.000 .000 & $\begin{array}{r}26.000 .0 \\
00\end{array}$ \\
\hline Sub Total & 5 & & 14.000 .000 & $\begin{array}{r}182.000 . \\
000\end{array}$ \\
\hline \multicolumn{5}{|l|}{ 2. Pekerjaan langsung } \\
\hline 1. Staf Produksi & 9 & 1.250 .000 & 11.250 .000 & $\begin{array}{r}146.250 \\
000\end{array}$ \\
\hline 2. Supervisor Proses Produksi & 1 & 2.000 .000 & 2.000 .000 & $\begin{array}{r}26.000 .0 \\
00\end{array}$ \\
\hline Sub Total & & & 13.250 .000 & 172.250 \\
\hline
\end{tabular}




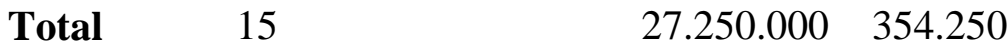

000

Sumber : data primer diolah

Tabel 5. Rincian Biaya Penyusutan

\begin{tabular}{ccrrr}
\hline Fasilitas & $\begin{array}{c}\text { Umur } \\
\text { Eknomis } \\
\text { (Tahun) }\end{array}$ & Nilai Awal (Rp) & Nilai Akhir (Rp) & \\
\hline Bangunan & 20 & 2.225 .454 .000 & 445.090 .800 & 89.018 .160 \\
Mesin dan peralatan & 10 & 1.250 .000 .000 & 125.000 .000 & 112.500 .000 \\
Total & & & 570.090 .800 & 201.518 .160 \\
\hline
\end{tabular}

Sumber : data primer diolah

Tabel 6. Rincian Biaya Produksi

\begin{tabular}{|c|c|c|c|c|c|}
\hline Uraian & Nominal & Satuan & Harga & Jmlh/Bln & Jmlh/Thn \\
\hline \multicolumn{6}{|c|}{$\begin{array}{l}\text { A. Biaya bahan baku \& } \\
\text { Penolong }\end{array}$} \\
\hline 1. Bahan Baku rumput laut & 1.000 & $\mathrm{Kg} / \mathrm{hari}$ & 5.500 & 137.500 .000 & 1.650 .000 .000 \\
\hline 2. $\mathrm{KOH}$ & 70 & $\mathrm{Kg} /$ hari & 15.000 & 26.250 .000 & 315.000 .000 \\
\hline 3. KCL & 5 & $\mathrm{Kg} /$ hari & 13.000 & 1.625 .000 & 19.500 .000 \\
\hline 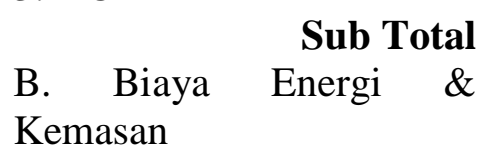 & & & & 165.375 .000 & 1.984 .500 .000 \\
\hline 1. Biaya kemasan & 300 & $\mathrm{Kg} /$ hari & 500 & 3.750 .000 & 45.000 .000 \\
\hline 2. Biaya BBM Solar & 75 & Liter/hari & 8.000 & 15.000 .000 & 180.000 .000 \\
\hline 3. Biaya Energi listrik & 100 & Kwh/hari & 878 & 2.195 .000 & 26.340 .000 \\
\hline $\begin{array}{r}\text { Sub Total } \\
\text { C. Biaya Personal langsung }\end{array}$ & & & & 20.945 .000 & 251.340 .000 \\
\hline $\begin{array}{l}\text { Biaya Tenaga Kerja } \\
\text { langsung }\end{array}$ & & & & 13.250 .000 & 172.250 .000 \\
\hline $\begin{array}{l}\text { D. Biaya Operasional \& } \\
\text { personal tak langsung }\end{array}$ & & & & & \\
\hline $\begin{array}{l}\text { 1. Biaya tenaga Kerja tak } \\
\text { langsung }\end{array}$ & & & & 14.000 .000 & 182.000 .000 \\
\hline $\begin{array}{l}\text { 2. Biaya Admin, Kom \& } \\
\text { Pemasaran }\end{array}$ & & & & 20.000 .000 & 240.000 .000 \\
\hline Sub Total & & & & 34.000 .000 & 422.000 .000 \\
\hline $\begin{array}{l}\text { Biaya Perbaikan \& } \\
\text { pemeliharaan }\end{array}$ & & & & & \\
\hline 1. Biaya Perbaikan alat & & & & 2.604 .167 & 31.250 .000 \\
\hline Uraian & Nominal & Satuan & Harga & Jmlh/Bln & Jmlh/Thn \\
\hline Pemiliharaan & & & & 2.781 .818 & 33.381 .810 \\
\hline Sub Total & & & & 5.385 .984 & 64.631 .810 \\
\hline Total Biaya Produksi & & & & 238.955 .984 & 2.894.721.810 \\
\hline
\end{tabular}

Sumber : data primer diolah 
Tabel 7. Produksi dan Hasil Penjualan

Uraian

Produksi ATC Chips (Kg/tahun)

Harga ATC Chips per kg

Total penjualan (Rupiah) per

\section{Nominal}

tahun

Sumber : data primer diolah

memberikan kemajuan perusahaan dari waktu ke waktu. Adapaun proyeksi laba rugi pabrik ATC Chips kapasitas 1000 kg/hari disajikan pada Tabel dibawah ini.

Tabel 8. Proyeksi Laba Rugi

\begin{tabular}{|c|c|c|c|c|c|c|c|c|c|c|c|}
\hline Uraian & Tahun 0 & Tahun 1 & Tahun 2 & Tahun 3 & Tahun 4 & Tahun 5 & Tahun 6 & Tahun 7 & Tahun 8 & Tahun 9 & Tahun 10 \\
\hline URAIAN & & TAHUN 1 & TAHUN 2 & TAHUN 3 & TAHUN 4 & TAHUN 5 & TAHUN 6 & TAHUN 7 & TAHU11 8 & TAHUN 9 & TAHUN 10 \\
\hline \multicolumn{12}{|l|}{ 1. Rogesi Feriugan } \\
\hline Total produk & 0 & 3.105000 .000 & 4.140.0000000 & 4.140.000,000 & 4.140.000,000 & 4.140.000.000 & 4.140 .0000000 & $4.140,000,000$ & 4.400 .000 .000 & 4.140 .000 .000 & $4.140 .000,000$ \\
\hline Jumlah Penjualan & 0 & 3.105 .000 .000 & $4.140,000000$ & $4.140 .000,000$ & $4.40,000,000$ & 4.140.000.000 & $4.440,000,000$ & $4.140,000,000$ & $4.40,000,000$ & 4.140 .000 .000 & $4.140,000,000$ \\
\hline \multicolumn{12}{|l|}{ 2. Bisja Prodksi } \\
\hline - Rentibelan Batan bakudan bahan penoobrg & 0 & 1488375.000 & 19844500000 & 1994.500 .000 & 19845000000 & 1984.5000000 & 19845000000 & 1984.5000000 & 19845000000 & 1984.500 .000 & 1.5845000000 \\
\hline - Biga bahan balar & 0 & 154765.000 & 2003340000 & 203.340 .000 & 208340,000 & $208,340,000$ & 208340000 & 2083440,000 & 208340.000 & 208340,000 & 206340,000 \\
\hline - Baja cererainal & 0 & 180.000 .000 & $240.000,000$ & 240.000 .000 & 240.000 .000 & 240.000 .000 & 240.000 .000 & 240.000 .000 & 240.000 .000 & 240.000.000 & 240.0000 .000 \\
\hline - Tengag aeria dodk angeging & 0 & 182000.000 & 1820000000 & 120.00 .000 & 1820000000 & 120.00 .000 & 1820000000 & 182000.000 & 1820000000 & 182000.000 & 182.0000000 \\
\hline - Tenaga Kega langeung & 0 & 172250.000 & 172250000 & 172280.00 & 172250.000 & 172.250 .000 & 1722500000 & 172250.000 & 1722500000 & 172250.000 & 172250.000 \\
\hline - Remellarazan bangunan & 0 & . & &. & $33: 381810$ & 32.381810 & 33.381810 & 33.381 .810 & 33381,810 & 33.381 .810 & $33: 381.810$ \\
\hline - Renelhararan alatdan mesin & 0 &. & 31250.000 & 31.250 .000 & 31250000 & 31.200000 & 31250.000 & 31250.000 & 31250.000 & $31.250,000$ & 312500000 \\
\hline - Bijag lentasan & 0 & 33.750 .000 & $45,000,000$ & $45,000,000$ & $45,000,000$ & 45.000.000 & 45.000 .000 & $45,000.000$ & $45,000,000$ & $45,000,000$ & $45,000,000$ \\
\hline Eaja Produksi & 0 & 2211.130 .000 & 2881340,000 & 2881.340 .000 & 2.84 .721 .810 & $2.84 .721: 810$ & 2894721.810 & 2894.721 .810 & 2.84 .721 .810 & 2894.721 .810 & 2.844 .721 .810 \\
\hline 3. Bija Praysustan & 0 & 201.518 .180 & 201.5181 .100 & 201.518 .180 & 201.518 .180 & 201.518 .100 & 201518.180 & 201.518 .100 & 201518.100 & 201.518 .100 & 201.518 .180 \\
\hline - Bangunan & 0 & 890.18 .180 & 89.0181100 & 89.018 .180 & 89.018 .180 & 80.018 .180 & 89.018 .180 & 89018.180 & 89018180 & 89018.100 & 89.018 .180 \\
\hline - Negindan Feralatan & 0 & 1125000.000 & 112500000 & $12.500,000$ & 1125000000 & 12.500 .000 & 1125000.000 & 1125000.000 & 1125000000 & 112500,000 & $112: 500,000$ \\
\hline Total Eaja produksi & 0 & $2,412848.180$ & 30028581100 & 3002.888 .100 & 3.0882299970 & 3.088 .29 .970 & 30982299970 & 3098.239 .970 & 3.088229970 & 3.098 .220 .970 & 3.0882299970 \\
\hline 4. Laba Usaha & 0 & 6922351.240 & 1077.141 .840 & 1077.41 .840 & 1.0437 .700 .030 & 1.043 .700 .030 & 10437800.030 & 10437800.030 & 1.0437800 .030 & 1043700.000 & 1.0437 .700 .030 \\
\hline 8. Pajak $($ PFH 25 & 0 & $207,706.652$ & 323.142562 & 32.42 .652 & 313.128 .009 & 313.128 .009 & 313.128 .009 & 313.128 .000 & 313.128 .009 & 313.128 .000 & $313,128.009$ \\
\hline Laba bersihtahun & 0 & 484.648 .288 & 7539999.288 & 753.999 .288 & 730.832 .021 & 730.832 .021 & 730.032 .021 & 730.028 .027 & 730.032 .021 & 730.028 .021 & 730.832 .021 \\
\hline
\end{tabular}

Sumber : data primer diolah

Tabel 9. Proyeksi Arus Kas

\begin{tabular}{lrrrrr}
\hline \multicolumn{1}{c}{ Uraian } & Tahun 0 & Tahun 1 & Tahun 2 & Tahun 3 & Tahun 4 \\
\hline Pemasukan & 0 & 3.105 .000 .00 & 4.140 .000 .000 & 4.140 .000 .00 & 4.140 .000 .00 \\
$\begin{array}{l}\text { 1.Hasil } \\
\text { Penjualan }\end{array}$ & 0 & 0 & 0 & 0 \\
2.Modal sendiri & 3.625 .454 .00 & 563.220 .000 & 0 & 0 \\
Arus Kas Masuk & 0 & & & & \\
& 3.625 .454 .00 & 3.668 .220 .00 & 4.140 .000 .00 & 4.140 .000 .00 & 4.140 .000 .00 \\
Pengeluaran & 0 & 0 & 0 & 0 & 0 \\
1.Biaya Investasi & 3.625 .454 .00 & & & & \\
& 0 & & 0 & & \\
2.Biaya Produksi & & 2.211 .130 .00 & 2.861 .340 .00 & 2.861 .340 .00 & 2.894 .721 .81 \\
& & 0 & 0 & 0 \\
3.Pajak(PPh25) & 207.705 .552 & 323.142 .552 & 323.142 .552 & 313.128 .009
\end{tabular}


$\begin{array}{llllll}\text { Arus Kas Keluar } & 3.625 .454 .00 & 2.418 .835 .55 & 3.184 .482 .55 & 3.184 .482 .55 & 3.184 .482 .55\end{array}$

$\begin{array}{rrrrr}0 & 2 & 2 & 2 & 2 \\ & 1.249 .384 .44 & 955.517 .448 & 955.517 .448 & 955.517 .448\end{array}$

\section{Selisih}

1.249 .384 .44
8

Saldo Awal 8

Kas Akhir

- 1.249 .384 .44

\subsection{7 .448}

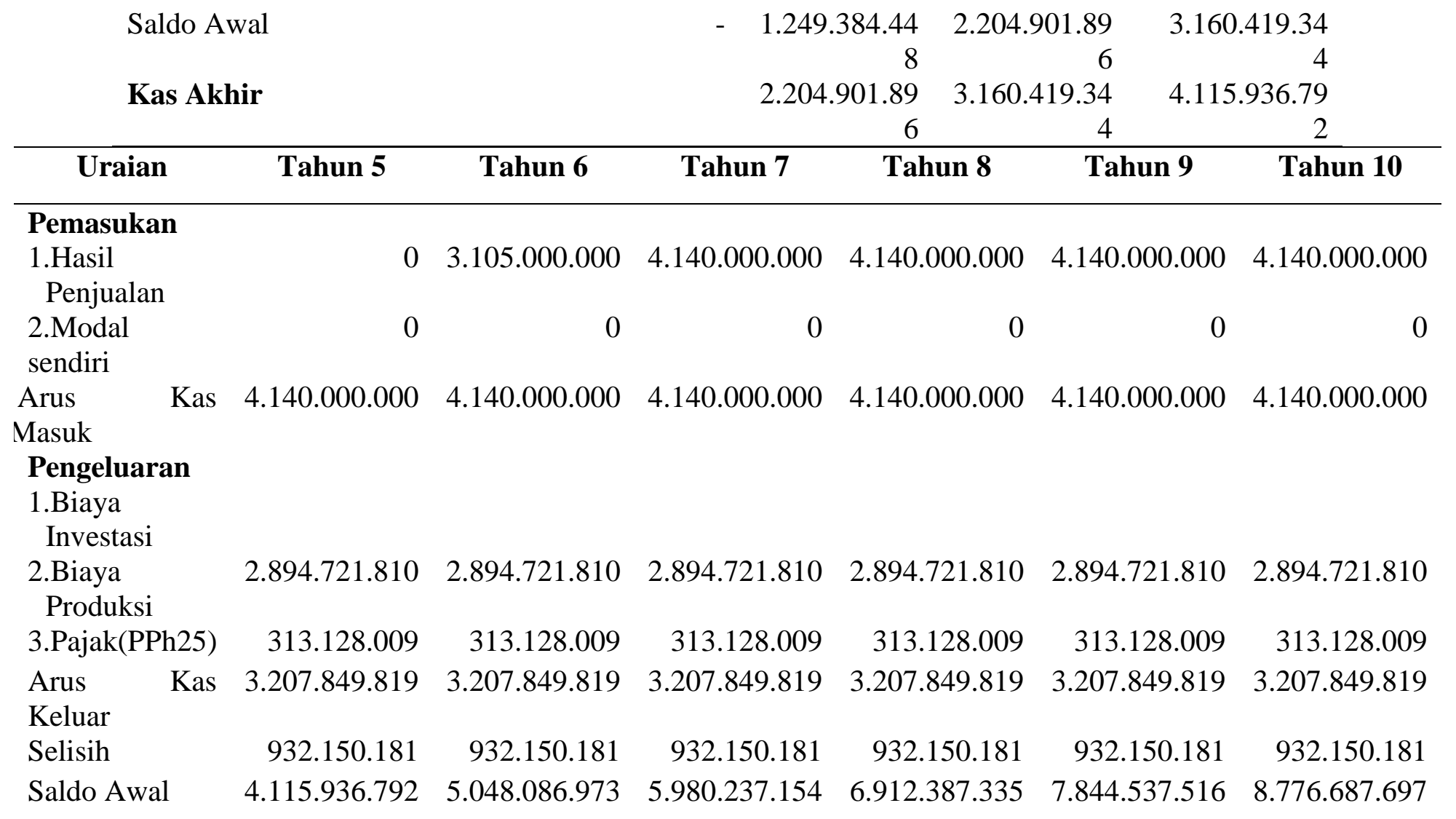


$\begin{array}{lllllll}\text { Kas Akhir } & 5.048 .086 .973 & 5.980 .237 .154 & 6.912 .387 .335 & 7.844 .537 .516 & 8.776 .687 .697 & 9.708 .837 .878\end{array}$

Tabel 10. Perhitungan Analisa Kelayakan

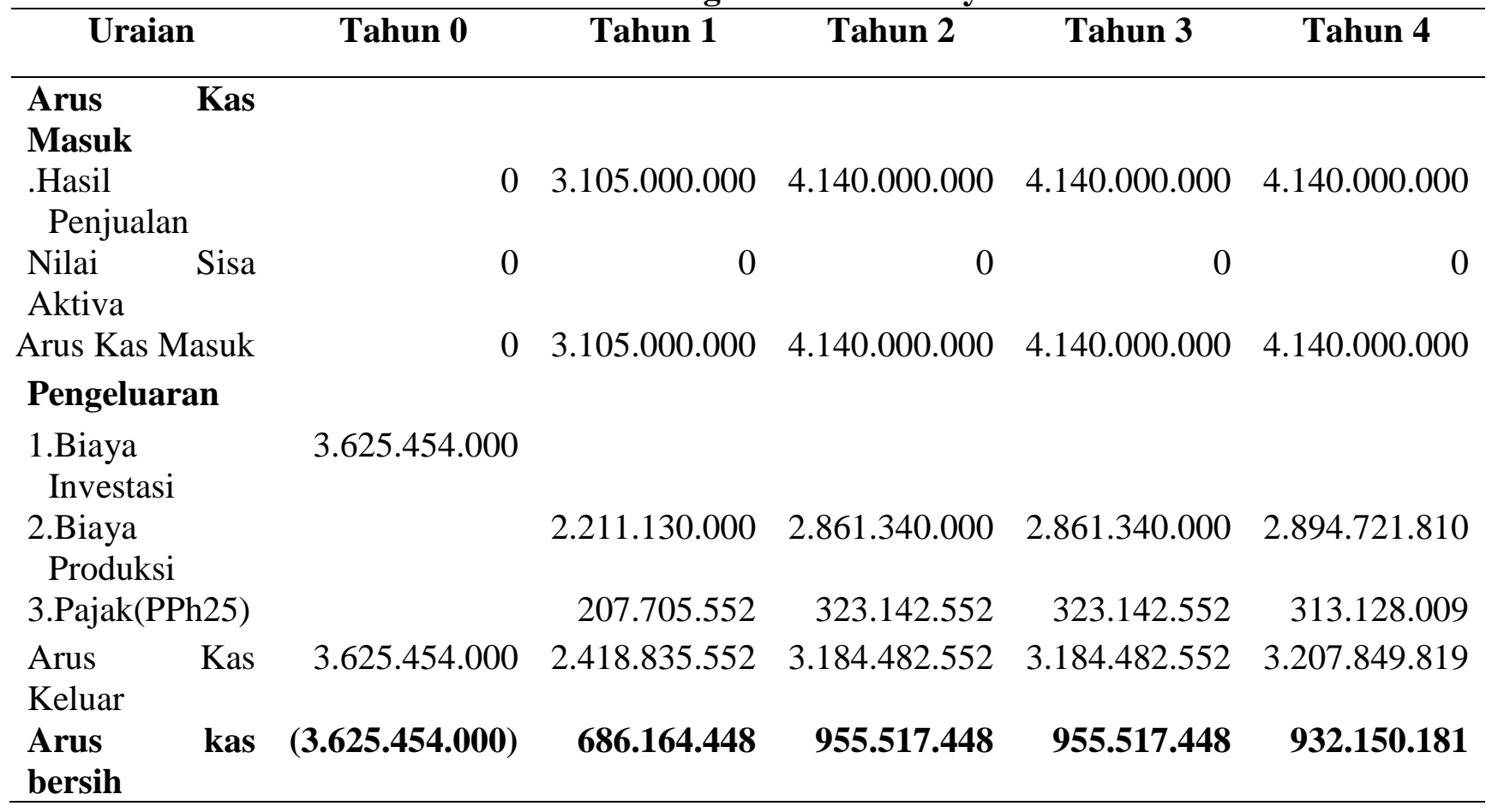

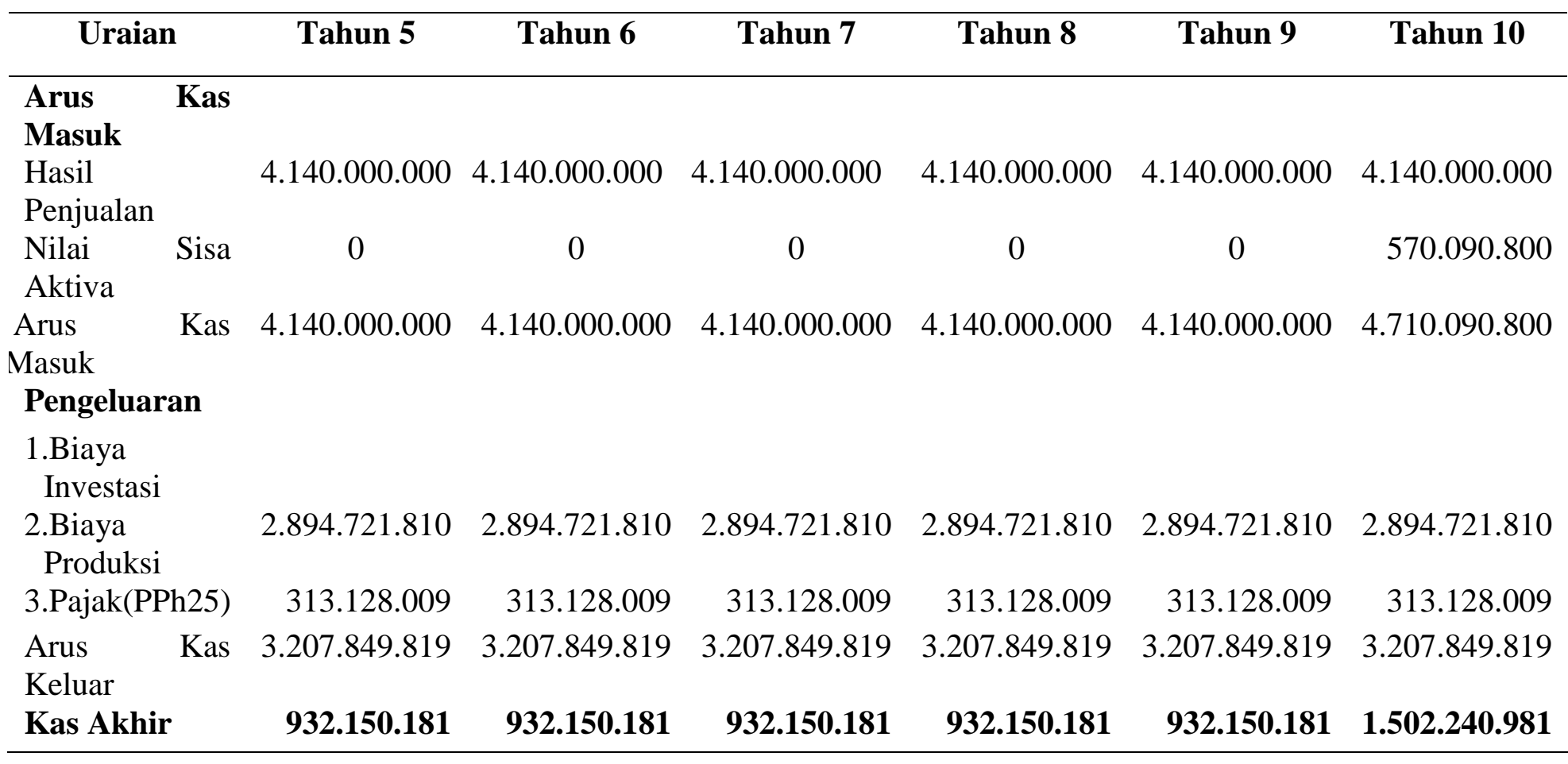

Tabel 11. Rekapitulasi Kriteria Kelayakan Investasi Industri ATC Chips Kapasitas $1000 \mathrm{Kg} /$ Hari Di Maluku Utara

NPV DF $15 \% \quad 1.012 .870 .549$




\begin{tabular}{lr}
\hline IRR & $21.7 \%$ \\
B/C Ratio & 1,29 \\
Pay back Period & 4,1 \\
Modal Investasi & 3.625 .454 .000 \\
Modal Kerja & 563.220 .000 \\
\hline
\end{tabular}

Sumber : data primer diolah

Tabel 12. Rekapitulasi Kelayakan Investasi Industri ATC Chips Kapasitas $1000 \mathrm{Kg} /$ Hari Di 7 (Tujuh) Propinsi

\begin{tabular}{|c|c|c|c|c|c|c|c|}
\hline Uraian & Sulsel & Sulteng & Sultra & NTB & NTT & Maluku & Malut \\
\hline $\begin{array}{l}\text { Harga RL } \\
\text { Kering }\end{array}$ & 6.000 & 6.000 & 6.000 & 6.100 & 6.300 & 5.500 & 5.500 \\
\hline $\begin{array}{l}\text { Harga } \\
\mathrm{KOH}\end{array}$ & 12.500 & 14.000 & 14.000 & 15.000 & 15.000 & 15.000 & 15.000 \\
\hline $\begin{array}{l}\text { Harga } \\
\text { KCL }\end{array}$ & 12.000 & 13.000 & 13.000 & 13.000 & 13.000 & 13.000 & 13.000 \\
\hline $\begin{array}{l}\text { Harga } \\
\text { ATC } \\
\text { Chips }\end{array}$ & 46.000 & 46.000 & 46.000 & 46.000 & 46.000 & 46.000 & 46.000 \\
\hline $\begin{array}{l}\text { NPV } \\
\text { DF15\%(0 } \\
00)\end{array}$ & 1.221 .624 & $\begin{array}{r}1.110 .71 \\
2\end{array}$ & 1.110 .712 & 939.303 & $\begin{array}{r}737.64 \\
5\end{array}$ & $\begin{array}{r}1.241 .79 \\
0\end{array}$ & 1.012 .870 \\
\hline $\begin{array}{l}\text { IRR } \\
\text { B } \quad \text { C }\end{array}$ & $\begin{array}{r}24.04 \% \\
1,39\end{array}$ & $\begin{array}{r}23.26 \% \\
1,36\end{array}$ & $\begin{array}{r}23.26 \% \\
1,36\end{array}$ & $\begin{array}{r}22.04 \% \\
1,30\end{array}$ & $\begin{array}{r}20.57 \% \\
1.24\end{array}$ & $\begin{array}{r}24.19 \% \\
1,40\end{array}$ & $\begin{array}{r}21.77 \% \\
1,29\end{array}$ \\
\hline $\begin{array}{l}\text { Ratio } \\
\text { Payback } \\
\text { Period }\end{array}$ & 3,77 & 3.87 & 3.87 & 4.13 & 4.23 & 3,76 & 4.07 \\
\hline $\begin{array}{l}\text { Modal } \\
\text { Investasi } \\
(000)\end{array}$ & 3.095 .000 & $\begin{array}{r}3.095 .00 \\
0\end{array}$ & 3.095 .000 & 3.095 .000 & $\begin{array}{r}3.095 .0 \\
00\end{array}$ & $\begin{array}{r}3.095 .00 \\
0\end{array}$ & $\begin{array}{r}3.625 .45 \\
4\end{array}$ \\
\hline $\begin{array}{l}\text { Modal } \\
\text { Kerja }\end{array}$ & 581.220 & 587.408 & 587.408 & 596.970 & $\begin{array}{r}608.22 \\
0\end{array}$ & 563.220 & 563.220 \\
\hline
\end{tabular}

\begin{tabular}{|c|c|c|c|c|c|c|c|}
\hline Uraian & Sulsel & Sulteng & Sultra & NTB & NTT & Maluku & Malut \\
\hline $\begin{array}{l}\text { NPV } \\
\text { ATC } \\
\text { Turun } \\
(000)\end{array}$ & 525.904 & 414.992 & 414.992 & 243.583 & 41.925 & 561.194 & 361.037 \\
\hline $\begin{array}{l}\text { IRRATC } \\
\text { turun 5\% }\end{array}$ & $19.01 \%$ & $18.18 \%$ & $18.18 \%$ & $16.89 \%$ & $15.33 \%$ & $19.28 \%$ & $17.38 \%$ \\
\hline $\begin{array}{ll}\text { NPV } & \text { RL } \\
\text { naik } & 5 \% \\
(000) & \end{array}$ & 872.000 & 755.542 & 755.542 & 575.562 & $\begin{array}{r}363.82 \\
2\end{array}$ & 908.298 & 723.265 \\
\hline $\begin{array}{l}\text { IRR RL } \\
\text { naik } 5 \%\end{array}$ & $21.55 \%$ & $20.70 \%$ & $20.70 \%$ & $19.38 \%$ & $17.80 \%$ & $21.81 \%$ & $19.69 \%$ \\
\hline
\end{tabular}

Sumber : data primer diolah

Analisis Kelayakan Finansial

Kriteria kelayakan yang dipakai meliputi NPV, PBP, Net B/C dan IRR yang dapat menggambarkan apakah proyek dapat direalisasikan atau tidak. Hasil perhitungan terhadap semua komponen kriteria kelayakan 
disajikan dalam Tabel diatas menggambarkan NPV yang positif, IRR diatas bunga Bank, $\mathrm{B} / \mathrm{C}$ ratio diatas seratus pesen, Pay back Period dibawah umur proyek serta dilakukan analisis sensitifitas keseluruhannya masih di zona yang menguntungkan jika industrialisasi rumput laut ini dilakukan di tujuh propinsi Indonesia Timur.

\section{SIMPULAN}

Berdasarkan hasil survai lapangan serta analisis terhadap data yang ada, dapat disimpulkan sebagai berikut . a) Kebutuhan rumput laut dunia sebagian besar dipasok dari Indonesia; b) Potensi rumput laut terbesar dan terbaik ada di Indonesia Timu; c) Industrialisasi Rumput Laut ATC Chips layak direalisasikan di tujuh propinsi Indonesia Timur (Sulteng, Sulsel, Sultra, NTB, NTT, Maluku dan Maluku Utara) dilihat dari kelayakan ekonomi dan finasialnya menunjukkan di zona positif berdasarkan hasil analisis Net Present Value, Pay Back Period, Internal Rate Of Return, Benfit And Cost Ratio.

\section{DAFTAR PUSTAKA}

J.T., Anggadireja. (2007). Prospek Pasar Rumput Laut Indonesia di Pasar Global, (7 Mei 2007).

J.T., Anggadireja, Ahmad Z., Heri P., S. A. (2006). Rumput Laut. Penebar Swadaya. Jakarta.

Anonim. (2013). Pengembangan Rumput Laut di Kabupaten Maluku Tenggara.

Irham, F. (2006). Analisis Investasi Dalam Persepektif Ekonomi Dan Politik. Bandung: Refika Aditama.

Sarwono, J. (2006). Metode Penelitian Kuantitatif \& Kualitatif. Yogyakarta: Graha Ilmu.

Poncomulyo, T. (2006). Budi Daya Dan Pengolahan Rumput Laut. Jakarta: PT Agro Media Pustaka.

Suryati, E., A. Parenrengi, R. S. (2007). Riset Pengembangan Rumput Laut melalui Kultur Jaringan dan Fusi Protoplas.
Hendrawati, T. Y. (n.d.). No Title. Analisis Kelayakan Industri Alkali Treated Cotonii Chips (ATC Chips) Dari Rumput Laut Jenis Euchema Cotonii, ISSN : 240.

Zatnika, A. (2009). Pedoman Teknis Budidya Rumput Laut. Badan Pengkajian dan Penerapan Teknologi. Jakarta. ) 
Direktur Jenderal Perikanan Budidaya Slamet Soebjakto bersama jajarannya saat memantau kegiatan pengeringan rumput laut hasil budidaya, di Kabupaten Sumba Timur, Nusa Tenggara Timur

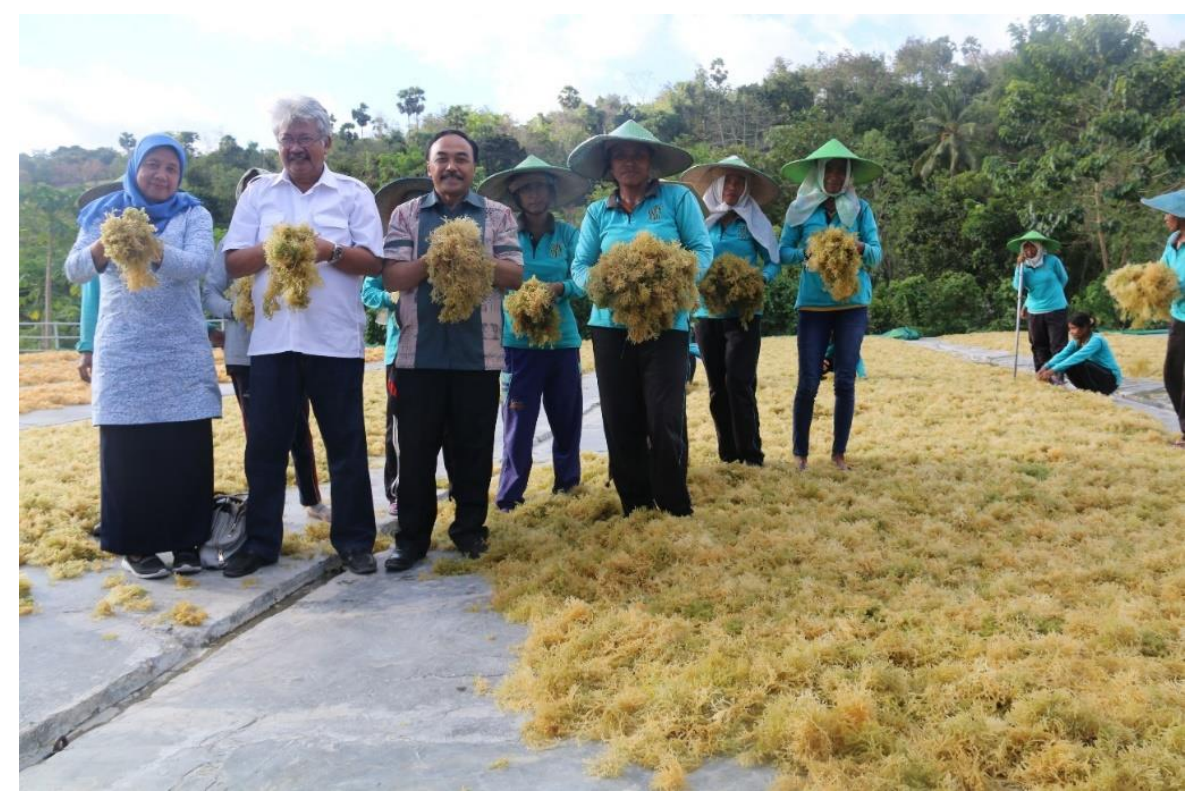

Sumber : http://news.kkp.go.id/wp-content/uploads/2017/08/WhatsApp-Image-2017-08-25-at-21.30.12-1.jpe

Kegitan Penerimaan Mahasiswa Baru Universitas Sanggga Buana Tahun 2017

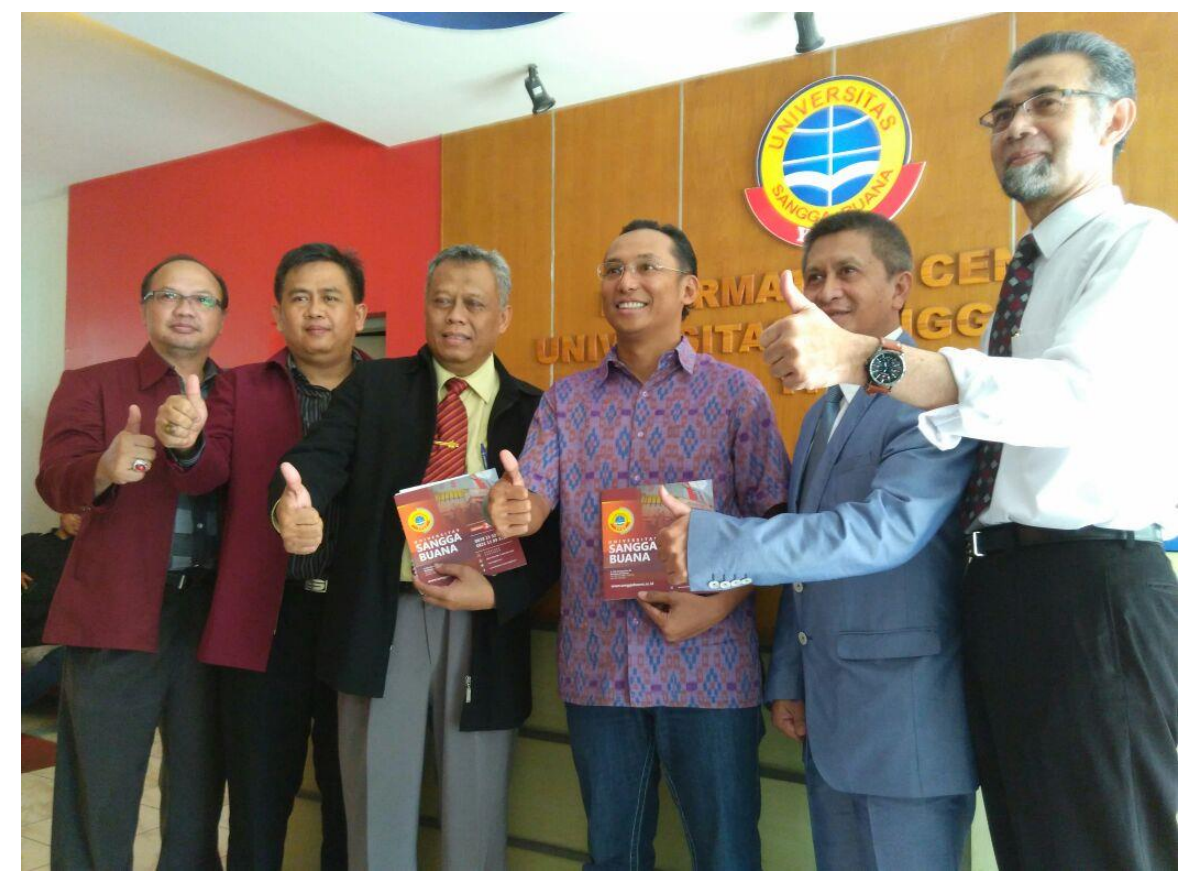

Sumber : http://arcom.co.id/wp-content/uploads/2016/09/IMG-20160917-WA0008.jpg 